\title{
LEADERSHIP AND INDIVIDUALITY IN THE ATHENIAN FUNERAL ORATIONS
}

\section{JON HESK}

If the most general property of an ideological discourse is to conceal the internal divisions of society, then there can be no doubt that the funeral oration functions, for the Athenian citizens, as an ideology, when it suppresses, within the civic army, the difference of status between combatants or when it makes the Athenian democracy the fatherland of arete. Whether it suppresses misthophoria, the rotation of offices, and the drawing of lots; whether it deprives democracy, grafted onto autochthonous origin, of any history; or whether it transforms stasis into a fine manifestation of unity, the funeral oration is trying to deny the existence of any division within the city. In this role, then, it is even more Platonic than Plato, who, in order to ensure the unity of the polis and the homoiotes between warriors, was not afraid to banish certain categories of inferior citizens to the periphery of the city. ${ }^{1}$

Nicole Loraux's argument concerning the ideological function of Athenian funeral speeches has been highly influential and deservedly so. The above passage is taken from her conclusion, and it is representative of her overall claim that each funeral oration repeats certain topoi in order to make the latest crop of Athenian dead seamlessly interchangeable with all the $\alpha \dot{\alpha} v \delta \rho \varepsilon \varsigma \alpha \dot{\alpha} \gamma \alpha \theta$ oì of the past who have achieved a fine death in the fulfilment of great and glorious military deeds. The point of these speeches was not just to memorialize the dead themselves or even to inspire others to perform similar acts of courage in the spirit of civic participation and security. The stability and traditionalism of the genre also contributed to what Loraux calls an 'imaginary Athens' - an 'ideality' which did the important ideological work of effacing and transforming the messy and negative 'realities' of Athens' past and present. In order to maintain this construction, the genre is allowed only a limited freedom: 'as a discursive institution, it is protected by its topoi against all innovations arising from changes in Athenian society'. ${ }^{2}$

Loraux has to admit that the funeral orations of the Thucydidean Pericles and Hyperides stretch the limits of the genre's alleged 'immobility'. Her argument is that these speeches' apparently innovative and unusual strategies are balanced by an excessive orthodoxy in their use of traditional topoi. For example, Hyperides' striking and unparalleled focus on the deeds of a named general who was among the war dead of 323/322 BC is balanced by his

\footnotetext{
${ }^{1}$ N. Loraux, The invention of Athens: the funeral oration in the classical city (Cambridge MA and London 1986) 330-31.

${ }^{2}$ Loraux, Invention (n.1, above) 330.
} 
traditional eulogy of all the soldiers (Hyp. 6.10-19). The genre regulates itself by using its traditional topoi as 'antibodies' against intrusive heterogeneous elements. ${ }^{3}$

For Loraux, the occasions when the funeral orations do celebrate the achievements of named historical individuals or identifiable sub-groups are exceptionally rare and, one way or another, they do not challenge the genre's stability. Nor, therefore, do they threaten the orations' concomitant projection of Athens as an unchanging polis populated by an undifferentiated collective of citizen-warriors whose courage ensures the city's everlasting survival and glorious reputation. In this article, I will argue that this account requires two forms of adjustment. First, we need to recognize that the naming of individuals and the individuation of sub-groups in these speeches qualifies, rather than merely strengthens, the 'ideality' of collective action. Secondly, we need to see that the significance and immediate reception of some of the funeral orations was affected by the identity of the orator who was chosen to deliver them and the historical particularities of their context of performance. The orations could sometimes highlight the orator's political involvement with the campaign. This involvement qualifies and nuances the ideological thrust of speeches' content as identified by Loraux.

These arguments add another dimension to recent reassessments of Loraux. Ian Morris argues that Loraux's account of funerary and commemorative practice is too static. ${ }^{4} \mathrm{He}$ points to changes in private burial practice after $425 \mathrm{BC}$ and an associated increase in monuments in which Athens' elite appropriates the communal symbols associated with the public funeral ceremony to memorialize individuals. Robin Osborne deals with shifts in the ideology governing the iconography of Attic funerary sculpture. ${ }^{5} \mathrm{He}$ concludes that the tendency for commemorating the war dead anonymously in public monuments came under increasing pressure in the later fifth century, eventually becoming replaced by private monuments. In this process, the Corinthian war was a turning-point. Prior to the erection of the Dexileos monument in $394 \mathrm{BC}$, the iconographic possibilities of depicting the fallen were confined to scenes of departure. After that date, it was possible to show the deceased in the moment of his death on the battlefield. The latest extant official list of war dead dates to 394/3, and the first honorific statues erected to individuals (Conon and Evagoras) appeared in the Agora at the same time. The first part of my argument will hopefully show that these shifts towards recognition of exemplary individuals find their analogues in the extant orations, albeit in a significantly mediated and diluted fashion.

The second half of my argument dovetails with Polly Low's recent point that the extant funeral orations are very diverse in the space they allot to discussion of war or detailed description of specific engagements. ${ }^{6}$ This is part-and-parcel of the 'multivalence' of the ceremony which Low traces in the literary sources and archaeology: a Lorauxian stress on the projection of democratic ideology and collective self-sacrifice must be balanced with the

\footnotetext{
${ }^{3}$ Loraux, Invention (n.1, above) 222.

${ }^{4}$ I. Morris, Death-ritual and social structure in Classical antiquity (Cambridge 1992) 128-55.

${ }^{5}$ R. Osborne, 'Democratic ideology, the events of war and the iconography of Attic funerary sculpture', in War, democracy, and culture in Classical Athens, ed. D. Pritchard (Cambridge 2010) 245-65.

${ }^{6}$ P. Low, 'Commemoration of the war dead in Classical Athens: Remembering defeat and victory', in War, democracy, and culture in Classical Athens, ed. D. Pritchard (Cambridge 2010) 341-58.
} 
ceremony's consolatory, honorific, and military functions. ${ }^{7}$ For me, another aspect to this 'multivalence' is the policy and particularity which we sometimes detect in the orator's voice. (By 'voice' I mean each speech's distinctive inflection of the genre and our sense of its impact in live performance.) The funeral-speech orator was sometimes heavily implicated in the very campaign whose dead he had been chosen to commemorate.

Before I proceed further, I should briefly outline my position on the questionable authenticity and authorship of nearly all of the speeches. We have a few quotations and possible paraphrases preserved in later authors from Pericles' speech delivered in 439 over those who had died in the costly campaign against Samos as well as anecdotes about its immediate reception. ${ }^{8}$ These later informants cannot be fully relied upon for unbiased or accurate testimony but I am primarily interested in the accounts' underlying assumptions about the functions of the funeral oration and the way in which it could be received. I do not believe these anecdotes would be plausible if their underlying assumptions were false.

The question of how far Thucydides' rendering of Pericles' speech in 431 is an accurate reflection of what he actually said is extremely vexed. Brian Bosworth offers some good arguments for accepting its basic accuracy and 'fit' with the historical situation and dispositions of the audience. ${ }^{9}$ But it is highly likely that Thucydides has shaped the speech in order to create resonances with the rest of the History. ${ }^{10}$ It has even been argued that the speech serves Thucydides' agenda to critique oratory's use of the past and illustrate the flaws of the epitaphioi logoi. ${ }^{11}$ My use of the speech only requires that we follow Carey in accepting that 'the broad tenor of the speech has been reproduced'. ${ }^{12}$ We only have a brief fragment of Gorgias' funeral speech (Gorgias D-K 82 B5-6). It is almost certainly an exercise rather than a transcript of an oration that was actually delivered at the demosion sema. To the extent that it clearly relies upon genuine funeral speech strategy in typically Gorgianic style, it can be used with care.

It is impossible to correlate Lysias' funeral speech 'for those who assisted the Corinthians' with a particular year's campaigning during the Corinthian War of 395-387 BC. This vagueness has seemed suspicious to some. It has also been argued that similarities between the speech and Isocrates' Panegyricus (c. $380 \mathrm{BC)}$ make its authorship and authenticity uncertain. ${ }^{13}$ It also seems unlikely that a metic would have been allowed and/or

\footnotetext{
${ }^{7}$ Other sophisticated analyses of the speeches which go beyond Loraux (and from which I have learned much): R. Thomas, Oral tradition and written record (Cambridge 1989) 196-237; L. Hardwick, 'Philomel and Pericles: Silence in the funeral speech', $G$ and $R 40.2$ (1993) 147-62; J. Grethlein, The Greeks and their past (Cambridge 2010); S. Yoshitake 'The logic of praise in the Athenian funeral oration', in War, democracy, and culture in Classical Athens, ed. D. Pritchard (Cambridge 2010) 359-77; J. L. Shear, “Their memories will never grow old": the politics of remembrance in the Athenian funeral orations', $C Q$ (forthcoming).

${ }^{8}$ Arist. Rhet. 1.1365a31-3, 3.1407a1-4, 3.1411a2-4; Plut. Per. 8.6 (incorporating Stesimbrotus FGrH 107 F 9) and 28.3-6 (incorporating Ion FrGrH 392 F 16).

${ }^{9}$ A. B. Bosworth, 'The historical context of Thucydides' Funeral Oration', JHS 120 (2000) 1-16.

${ }^{10}$ See, e.g., W. Robert Connor, Thucydides (Princeton 1984) 52-78; T. Rood, Thucydides: Narrative and explanation (Oxford 1998) 193-98.

${ }^{11}$ Grethlein, Greeks and their past (n.7, above) 220-40.

${ }^{12}$ C. Carey, 'Epideictic Oratory', in A companion to Greek rhetoric, ed. I. Worthington (Malden 2007) 242.

${ }^{13}$ Details, debate, and further bibliography: S. Todd, A commentary on Lysias speeches 1-11 (Oxford 2007) 149-64.
} 
chosen to deliver an epitaphios logos in person. I will be assuming that the speech is at the very least an accurate reproduction of what a real funeral speech should have sounded like.

I will not make much reference to the funeral speech which Socrates claims to have been taught by Aspasia in Plato's Menexenus. It anachronistically refers to events after Socrates' death and some have argued that it explicitly and critically engages with both the rhetoric of Thucydides' speech and that of Lysias. Few now doubt that Plato wrote the Menexenus but debate as to how far its speech is a philosophical critique of the epitaphios logos, a parody, or a tongue-in-cheek pastiche is ongoing. ${ }^{14}$ However, the speech does help us with generic trends, and the dialogue's opening discussion of the mechanics of selection, production, and reception of the epitaphioi logoi is historically useful.

We know from a later lawcourt speech that Demosthenes delivered the funeral oration that commemorated the Athenians who died in the heavy defeat at Chaeronea (Dem. 18.285). But scholars are divided as to whether the extant funeral oration which purports to be that speech is genuine. I follow the arguments of Herrman, Worthington, and earlier scholars cited by them in seeing it as genuine. ${ }^{15}$ Ironically, the only funeral speech whose authenticity is not in any serious doubt is the one which is regarded as the most 'atypical'. Hyperides delivered his funeral speech in commemoration of the Athenians who had died in the first year of the Lamian War. The papyrus text is fragmentary and has required extensive conjectural restoration by successive generations of editors. ${ }^{16}$ I will begin the first part of my argument with this last surviving example of an Athenian funeral speech.

\section{(a) Individuals and sub-groups}

Hyperides' epitaphios logos was likely delivered in the spring of $322 \mathrm{BC}$ after the first year of the Lamian War. At this point, Athens had done well in this war of resistance against Macedon. She had won an initial victory in Boeotia. The siege at Lamia resulted in a Greek victory and the death of the Macedonian general Leonnatus. But Leosthenes, the Athenian general who had been the main military architect of these victories, was killed as the siege moved into the winter. The Athenian Boule had commisioned him to levy a mercenary army early in 323. When Alexander died later that year, the Athenians moved to make war on Macedon. Hyperides, an anti-Macedonian politician through and through, persuaded the Athenian assembly to approve a large Athenian force to join up with the mercenaries. Demosthenes and Hyperides were busy recruiting allies in the Peloponnese while Leosthenes laid siege to routed Macedonian forces at Lamia. ${ }^{17}$

\footnotetext{
${ }^{14}$ Debate and further bibliography: B. Rosenstock, 'Socrates as revenant: A reading of the Menexenus', Phoenix 48.4 (1994) 331-47; S. Monoson, Plato's democratic entanglements (Princeton 2000) 181-205; J.-P. Pradeau Plato and the city, trans. J. Lloyd (Exeter 2002) 14-42; M. Schofield and T. Griffth, Plato. Gorgias, Menexenus, Protagoras (Cambridge 2010) xviii-xxii, xlii.

15 J. Herrman, 'The authenticity of the Demosthenic funeral oration', AAHung 48 (2008) 171-78; I. Worthington, 'The authorship of the Demosthenic epitaphios', MH 60 (2003) 152-57. C. Carey, 'Epideictic Oratory' (n.12. above) 242 is agnostic.

${ }^{16}$ I am using the edition of J. Herrman, Hyperides. Funeral Oration (Oxford 2009). Herrman gives a useful account of the issues and previous editors' approaches (27-34).

${ }^{17}$ For more on this complex political and military historical background, see O. Schmitt, Der Lamische Krieg (Bonn 1992); J. Engels, Studien zur politischen Biographie des Hypereides (Munich 1993). Herrman, Funeral
} 
Hyperides' speech is strikingly unique when compared to the other extant speeches because it names Leosthenes and extensively commemorates his qualities and actions in the recent campaign. There is an emphasis on his powers of leadership and persuasion. ${ }^{18}$ This focus on Leosthenes displaces the usual catalogue of glorious Athenian military actions from the past. ${ }^{19}$ Hyperides explains that there is 'not enough time now' to survey individually the city's 'earlier accomplishments' (6.4). And unlike the Thucydidean Pericles who narrates the values and virtues of the city at length, Hyperides uses an economical and philosophically rich, cosmic simile - comparing Athens to the sun - to stand for any detailed praise of the city's values, structures, and past exemplary actions (6.4-5) ${ }^{20}$ His appeal to the autochthonous origins of all Athenian men as obviating the need to trace the history of individual gene is more conventional (6.6-7). ${ }^{21}$ But Hyperides is quick to dismiss the usual practice of praising and detailing the dead men's paideia: their manifest virtue means that their good eduation is self-evident (6.8-9).

Through these techniques of praeteritio, Hyperides gives himself the space to narrate at some length the events of the previous year: the success in Boeotia, the siege of Antipater at Lamia and the defeat of Leonnatus. He gives Leosthenes' skills and decision-making great prominence throughout. Although Lysias' and Plato's speeches do mention the campaigns whose dead they are celebrating, they place much greater stress on an idealized history of Athens, which starts in the mythological past and culminates in the Persian Wars. As Judson Herrman puts it, the traditionally brief treatment of the campaign at hand in comparison to those of the past is 'as if to emphasize that the current honorands play but a small part in a great tradition'. ${ }^{22}$ Demosthenes' funeral speech is rather different: nearly half the speech is focused on Chaeronea and the character and exploits of its Athenian casualties (60.15-31). But Hyperides clearly overturns the traditional approach to a much greater extent than Demosthenes. And this is apparent, not just in the time spent on the Lamian campaign and Leosthenes' virtues, but also in the manner of their presentation. For example, Leosthenes and his men have done something that is even better than the Athenians' performance in the Persian Wars, not to mention the Greek heroes' efforts at Troy $(6.35-38){ }^{23}$ These heroes have surely welcomed and admired Leosthenes in Hades (6.38). Hyperides then imagines that Harmodius and Aristogeiton consider Leosthenes and his men to be their closest associates in the underworld. The former did away with the tyrants of their native city, whereas the latter destroyed the tyrants of the whole of Greece (6.39).

How are we to explain this unusual focus on Leosthenes and the year's campaign? Part of the answer must be that it conforms to what Herrman has called 'the rhetoric of revolt'

Oration (n.16, above) 1-14 offers a succinct narrative and more bibliography. See also D. Whitehead, Hyperides. The forensic speeches (Oxford 2000).

${ }^{18}$ Hyp. 6.1, 3, 6, 10-15, 24, 33-41.

${ }^{19}$ Contrast Lys. 2.3-16, 20-66; Pl. Menex. 239a-246b; Dem. 60.6-12. Compare Thuc. 2.36. Demosthenes' effort is very cursory but his unique account of the tribal heroes' exemplary actions at Dem.60.27-31 has to be factored in.

${ }^{20}$ Contrast Pericles at Thuc. 2.37-41. See also Dem. 60.25-26.

${ }^{21}$ See Thuc. 2.36; Lys. 2.17; P1. 237b-c; Dem. 60.4.

${ }^{22}$ Herrman, Funeral Oration (n.16, above) 20. See also Grethlein, Greeks and their past (n.7, above) 105-25.

${ }^{23}$ This is to go beyond Lys. 2.67-70 and Dem. 60.10-11. 
which emerges when we compare this speech with Hyperides' Against Diondas and the Demosthenic On the treaty with Alexander. ${ }^{24}$ Hyperides was one of a number of rhetores who had been engaged in a factional struggle after the defeat at Chaeronea over the question of resistance against Macedon. The unusual features of our funeral oration then look like a continuation of that rhetoric. Leosthenes is being memorialized and heroized as an inspiring figurehead for the 'revolt' and Hyperides uses his example as a means of strengthening support for the war with Macedon. We will return to Hyperides' prominent role as a zealous, anti-Macedonian politician in the next section. But why was it even possible for him to depart from the conventional topoi of the epitaphios logos and construct his rhetoric around Leosthenes? We still need an account of how this was acceptable in ideological terms.

The usual explanation is that Athenian life, thought, and culture in the late fourth century $\mathrm{BC}$ allow a much greater valorization of individual achievements at the expense of collective ones than they did in previous decades. ${ }^{25}$ Hyperides' lavish attention on Leosthenes might in part be inspired by the model of fourth-century prose encomia of individuals: there is Xenophon's Agesilaus, Isocrates' Evagoras, Theodectes' lost praise of Alexander of Epirus, and Philiscus' lost encomium of Lycurgus. Allied to this explanation is Loraux's point that 'we know of the ever increasing importance acquired by exceptional individuals from the end of the fifth century'. ${ }^{26}$ She cites the monument to the Spartan general Lysander at Delphi, but the Athenian statues to Conon and Evagoras are more relevant, as is the democracy's practice of awarding crowns to benefactors. Hyperides certainly stresses that Leosthenes was the 'author of the decision for the city and he was appointed the leader of the expedition for the citizens'; he tells us that 'good planning depends on the general'. ${ }^{27}$ But Loraux's gloss of all this as meaning that 'the citizen merely has to comply with the will of the hegemon' does not do justice to a speech, which balances its construction of Leosthenes as a prime-mover with reminders that it was the polis which ultimately chose to make war and that the Athenian troops themselves chose to die with valour. $^{28}$

Diodorus appears to claim that Leosthenes was given a hero's funeral. ${ }^{29}$ If true, then this would add further weight to the idea that the speech reflects a general trend towards the singling out of exceptional generals for special honours and mentions. However, Diodorus' wording is not clear-cut. And an official heroization of Leosthenes seems unlikely when we consider that Hyperides' speech expresses open indignation both at the enemy's imposition of ruler-cult and the recent heroization of Alexander's companion Hephaistion (Hyp. 6. 21). ${ }^{30}$ Indeed, this spirited attack on these despotic, Macedonian practices points to a real problem with the explanations mooted in my previous paragraph. Hyperides' singling out of

\footnotetext{
${ }^{24}$ J. Herrman, 'Hyperides' Against Diondas and the rhetoric of revolt', BICS 52 (2009) 175-85.

${ }^{25}$ Loraux, Invention (n.1, above) 111; Herrman, Funeral Oration (n.16, above) 61.

${ }^{26}$ Loraux, Invention (n.1, above) 111.

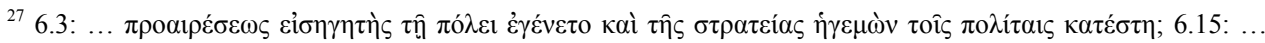

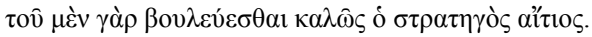

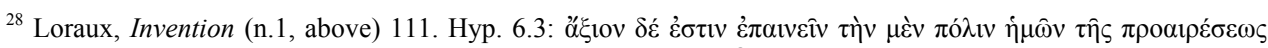

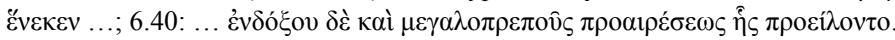

${ }^{29}$ Diodorus Siculus 18.13.5

${ }^{30}$ Loraux, Invention (n.1, above) 112.
} 
Leosthenes for praise threatens to dissolve the wonderfully crisp antithesis between praise of collective, anonymous Athenian bravery on the one hand and the idolatrous practices of Macedonian tyranny on the other. Was Hyperides really so enthralled by a new individualism that he could not stop himself from blurring this rhetorically powerful opposition?

I think the answer to this question is that the genre may have offered Hyperides more precedents for the naming and praising of individuals and sub-groups within the polis than is generally assumed. However, it will not do to argue that individual generals had to be singled out in an epitaphios logos if they had died in that year's fighting. Athenian generals did not die in the field all that often. ${ }^{31}$ But, aside from Leosthenes, one general seems definitely to have been killed in a campaign which coincides with an extant oration. Callias died in 432/431 BC during the revolt of Potidaea, but he is not mentioned by Pericles in the Thucydidean version of the oration at the end of the season. There is also some very slight evidence that the general Stratocles might have died at Chaeronea. ${ }^{32}$ If he did, we have no mention of him in Demosthenes' oration.

Where might we look for another funeral speech which incorporated praise of an individual general? Adrastus' eulogy over the recovered bodies of the Seven in Euripides' Supplices would be an obvious example from the 420s or 410s, because the Argive king names and praises five of the seven warriors individually (Eur. Supp. 857-917). ${ }^{33}$ They are not just praised for their military courage: private, non-martial, and polis-friendly virtues are stressed, too. ${ }^{34}$ Of course, it could be argued that Adrastus' naming and praising of these individual heroes as models for the young to emulate is a marker of the difference between non-democratic, Argive commemorative practice from the mythic past and that of contemporary Athenians. Adrastus and the Seven are highly problematic figures rather than positive models in this tragedy. On the other hand, the Euripidean version does match the prose epitaphioi logoi in its acknowledgment of the grief of relatives and families and their sense of loss. ${ }^{35}$ And we should remember that the terms of Adrastus' praise are dictated by the initial request of the Athenian king Theseus that he explain how these heroes acquired their pre-eminence in courage for the benefit of 'the sons of these citizens' (11. 841-42). The notion that actions performed by the heroes of one's polis are exemplary for military courage and self-sacrifice is explicitly taken up with reference to individual eponymous heroes of the ten Athenian tribes in Demosthenes' funeral speech (60.27-32).

Furthermore, the retrieval of the bodies of the Seven is itself a topos within the funeral speeches' narratives of past Athenian engagements. ${ }^{36}$ Of course, Theseus is never named in this or other topoi which describe expeditions associated with him. It is undeniable that the extant funeral speeches seem to suppress the names of all the Athenian kings associated within their narration of such mythical exploits while often allowing their enemies to be

\footnotetext{
${ }^{31}$ One evidence-gathering exercise discovers only 38 Athenian generals who died in battle between 501/500 and 322/321: D. Hamel, Athenian generals: Military authority in the Classical period (Leiden 1998) 204-09.

${ }^{32}$ For the details, see Herrman, Funeral Oration (n.16, above) 62.

33 The precise date of this play is impossible to determine: see J. Morwood, Euripides: Suppliant women (Warminster 2007) 26-30.

${ }^{34}$ For good remarks and further bibliography, see Morwood, Suppliant women (n.33, above) 14-17 and 209-17.

${ }^{35}$ See C. Pelling, 'Conclusion', in Greek tragedy and the historian, ed. C. Pelling (Oxford 1997) 229-35.

${ }^{36}$ Lys. 2.7-10; Pl. Menex. 239b; Dem. 60.8.
} 
named. But when (for example) Demosthenes describes how 'the ancestors of the present generation' defeated the Amazons, this would surely activate a recollection of Theseus' involvement in that story? ${ }^{37}$ It seems to me that the emphasis on Athenian anonymous collective agency in the funeral speeches' allusions to these stories tells the audience that Athens' legendary kings relied heavily on their ancestors to achieve these victories rather than erasing those kings' agency and leadership altogether.

Because we have only Thucydides' version of a funeral speech for the fifth century and but a few lines of Pericles' speech of 439, it is in any case dangerous to assume that fifthcentury epitaphioi logoi could not name (what we would call) mythical Athenian figures or historical Athenian individuals. Two of the fourth-century funeral speeches certainly name historical generals who, though long dead, were associated with the ideologically significant victories of the Persian wars. Lysias' epitaphios logos names Themistocles and praises his role as the leader of the Athenians who fought at Salamis (Lys. 2.42):

These men achieved many glorious deeds for the freedom of Greece. Themistocles was their general, a man best prepared in speech and judgement and action. Their ships outnumbered those of the allies put together, and their men were the most experienced. $^{38}$

Avezzù and Todd see Themistocles as key to Athens' adoption of democratic imperialism and argue that he is mentioned because Lysias' speech aligns itself with that ideology. ${ }^{39}$ But it is notable that Lysias lists Themistocles' own distinctive skills and virtues here and there is a clear implication that the size and experience of the Athenian fleet is due to him.

This is not the only time that Themistocles appears in the epitaphioi logoi. Hyperides names him alongside Miltiades (Hyp. 6.37-38):

As for those who lived after these men [i.e. the Greeks who captured Troy], whose accomplishments were worthy of their ancestors' virtue, I mean those who fought with Miltiades and Themistocles and the rest, the ones who by freeing Greece conferred honour on their native city, and who made their own lives glorious, this man [i.e. Leosthenes] excelled them in courage and cunning, since they warded off the barbarian force when it was already invading, while he did not allow it even to enter. ${ }^{40}$

Hyperides' naming of the two generals here is clearly a means of quickly distinguishing the Athenian successes in the Persian Wars from many other battles. But it also serves

${ }^{37}$ Dem. 60.7-8. Of course, Theseus is named alongside other eponymous heroes and their children at Dem. 60.27-32. On Theseus' 'suppression' see discussion and bibliography in Herrman, Funeral oration (n.16, above) 68-70.

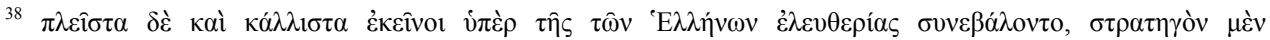

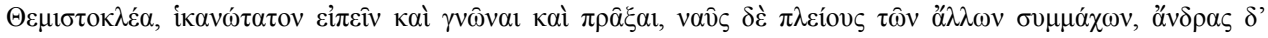

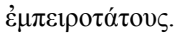

${ }^{39}$ G. Avezzù, 'Temistocle e Mironide nell'Epitafio di Lisia (LYS. Or. II 42 e 52)', SIFC III, 5 (1988) 58-65; Todd, Commentary (n.13, above) 245.

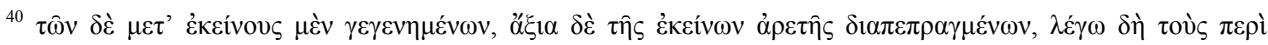

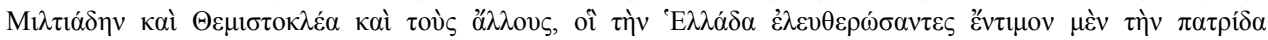

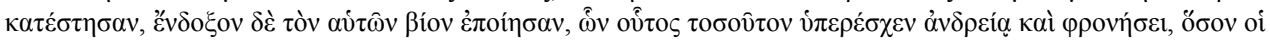

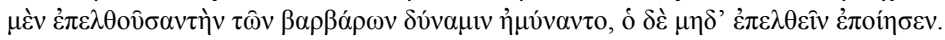


Hyperides' wider aim to couple the achievements of Leosthenes with those of his men and then to claim that these achievements are greater than all previous ones in history. Unlike Lysias, Hyperides does not attribute distinctive virtues to Themistocles. But there is a clear implication that both he and Miltiades possessed andreia and phronēsis - even if Leosthenes surpassed them in the exercise of these virtues. So, Lysias uses a long-dead, famous general to foreground qualities and which should be emulated both by present and future generals and the anonymous rank and file. Hyperides names two famous generals from the past in order to underline the reasons why a recently killed general and his men should be the objects of praise and emulation.

Of course it could be argued that Lysias' naming of Themistocles as early as the 390s is just an exception which proves a rule: individual leaders do not do usually get named and memorialized and Themistocles gets special license both because of Salamis' ideological significance and because he is long dead. But Lysias also names the general Myronides as the leader in a rather surprising narrative of the Geraneia Campaign of c. 458 BC (Lys. 2.52). The Geraneia narrative is included at the expense of more obvious and major fifthcentury campaigns, such as that at Eurymedon. Stephen Todd follows others in seeing this section as a direct adaptation of Thucydides' account (Thuc. 1.105-6). ${ }^{41}$ He must be right that Lysias mentions this campaign because it develops further the speech's theme of 'heroic isolation': Lysias reminds his audience that Athens refused to recall its regular troops from campaign to defend Geraneia and instead used reserves from below and above normal military age (Lys. 2.50-53). It is 'the sort of episode that catches the imagination'. ${ }^{42}$

The unusual naming of Myronides gives Todd great difficulty: 'I have no good explanation for the mention of Myronides (the comic poets appear to have regarded him as a representative of the good old days, but not uniquely so), unless he has possibly crept in as a result of Lysias' close use of Thucydides' narrative in this part of the speech'. ${ }^{43}$ One explanation is that the implicit prohibition on naming Athenian individuals is just a mirage created by our scanty evidence. If we had more funeral speeches, we would hear more generals and heroes named and praised (albeit minimally).

Another explanation would be that the prohibition was real but became relaxed over time. Thus, we could relate Lysias' naming of both Themistocles and Myronides to the changes in monumental practice discussed by Osborne. In the late fifth and early fourth centuries, there is a marked move towards the memorialization of military leaders on monuments and an increased tendency to set up private memorials to individual warriors. This is then reflected in a slight loosening of the ideological prohibition on naming individuals in the epitaphioi logoi.

Either of these explanations would undoubtedly gain plausibility if there were any individual, 'historical' Athenians named in Demosthenes' speech of 338. However, we ought not to expect the Athenian generals presiding over a cataclysmic defeat like Chaeronea to be named, even if any of them did die in the field. Indeed it is part of Demosthenes' strategy in this speech to shift blame for the defeat onto the operations of chance, divine will, and the poor leadership of the Thebans (Dem. 60.21-22). It was admittedly open to Demosthenes to

\footnotetext{
${ }^{41}$ Todd, Commentary (n.13, above) 249-50. See also Thomas, Oral tradition (n.7, above) 202 and 227-29.

${ }^{42}$ Todd, Commentary (n.13, above) 250.

${ }^{43}$ Todd, Commentary (n.13, above) 252.
} 
mention fifth- or early fourth-century generals as he recounted the key glorious campaigns of the past, especially the Persian wars (60.4-11). But he passes over that past very allusively and swiftly indeed. He prefers to focus on the virtues and civic upbringing of the dead of Chaeronea themselves. And of course, there are plenty of named 'mythical' Athenians in his list of the exemplary actions of the eponymous heroes and their offspring (60.27-31). It seems to me, then, that the particular circumstances of Chaeronea and Demosthenes' rhetorical-strategic response to it go a long way to explaining why Demosthenes' speech has no named 'historical' Athenians in it.

Nor should we place too much weight on the mere occurrence or absence of a named historical/mythical Athenian. We have already seen how certain stories would evoke the thought of an individual Athenian hero despite his not being named. And we have seen how different is Lysias' rhetorical use of Themistocles from that of Hyperides. Another important aspect to the rhetorical and ideological force of the naming of Athenian heroes and generals in the funeral speeches lies in their interaction with the identification of sub-groups within the anonymized collective past of warriors. When Myronides gets his mention in Lysias' speech, it is crucial to realize that he is only identified once the unusual character of his contingent has been established (2.50-53):

The Athenians had the courage not to recall a single soldier, either of those who were far off or of those who were close at hand. The older men, and those who were still under age, trusted in their own bravery and held their attackers in contempt. They decided to face the danger on their own, because one group of them was courageous as a result of experience, and the other group by nature. The first group had often displayed their bravery, and the others were copying them; the older ones knew how to take command, and the younger ones were skilled at doing what they were ordered. Under the leadership of Myronides as general, they marched out to the Megarid, and they defeated in battle the full force of their enemies by means of those who had already lost their strength and those who were not yet powerful. [...] Some of them were no longer strong, others were not yet strong, but both groups showed themselves superior in courage. After returning home with a fine reputation, the one group resumed their education, the other their counsel for the future. ${ }^{44}$

The usual way to read this passage is as a paradoxical reinforcement of the key ideological messages of the epitaphios logos. For Loraux, 'the orator uses a cleavage within the city that crystallizes within itself all the oppositions dear to the funeral oration in order to show, even within diversity, the unity of Athenian valor' ${ }^{45}$ For Grethlein, 'the

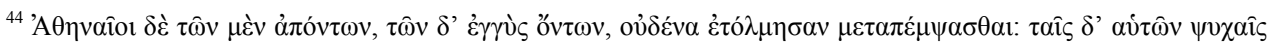

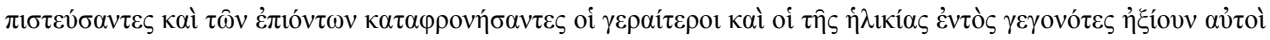

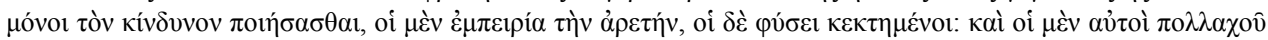

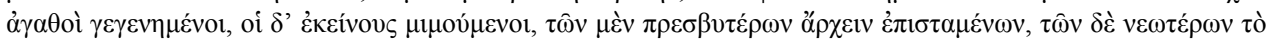

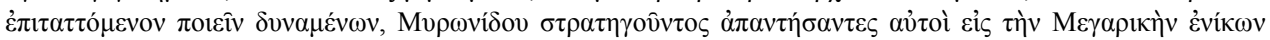

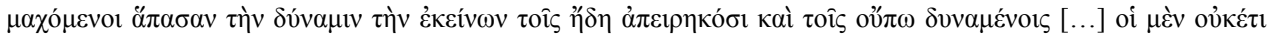

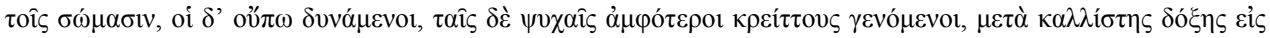

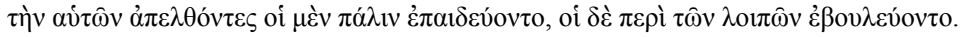

${ }^{45}$ Loraux, Invention (n.1, above) 135.
} 
cooperation of the two generations demonstrates that the continuum of Athenian history is based on imitation of the ancestors by each new generation'. ${ }^{4}$

These readings do not quite do justice to the ideological complexity of the Geraneia narrative. Note that the sub-group of youths who are below normal military age do not just imitate the sub-group of older men. They are also 'skilled at doing what they were ordered'. In turn, the old men are not just brave and experienced. They 'knew how to take command'. Thus the importance of hierarchy and the ability to lead and be led are underlined as crucial elements of military success. On top of this, the passage implies that the discipline of the youths was connected to their current status as recipients of paideia, while the old men were able to take command because of a long-held role as deliberators and advisers. In the midst of all this, we have the implication that Myronides' overall command made a difference, too. His generalship is mentioned in the very sentence which makes it clear that this was a victory in which the weaker side defeated the stronger. Specific sub-groups of atypical Athenian warriors and their generals are represented as being successful by virtue of their distinctive and differentiated roles and identities. Admittedly, the emulation of elders and the harnessing of an innate, undifferentiated, transhistorical Athenian excellence is part of the message. But this is supplemented with the recognition that different constituencies in the city (including named leaders) each contribute to the achievement of that excellence by virtue of their difference.

This logic and its ideological force is also apparent in Demosthenes' argument that the men who gave their lives at Chaeronea were partly inspired to do so because of their membership of one of the ten Cleisthenic tribes (60.27-31). His conceit is that the war-dead were inspired to choose a fine death by the various stories attached to their tribal heroes. The troops are allowed to have followed the example of named mythical, aristocratic heroes, heroines, and kings; and, one tribe is permitted to have been motivated in a very different way to another. Thus the Aegeidae choose to die rather than live without the iségoria ('equal rights to speak') introduced by Aegeus' son Theseus (60.28). But the Pandionidae choose valorous death so as not to fall short of the courage of women, namely the heroines Procne and Philomela (60.28). The Aeantidae followed their tribal hero Ajax in preferring death to the ignominy of life without the spoils of valor (60.31).

Loraux claims that Demosthenes here 'reduces proairesis ['choice'] to an imitation of the exemplary proairesis of the Eponyms'. ${ }^{47}$ This is part of her argument that both Demosthenes' and Hyperides' speeches circumvent the genre's usual representations of the Athenian warrior's death as the outcome of a choice preceded by deliberation. But nowhere in Demosthenes' catalogue of mental processes through which each tribal sub-group came to accept a fine death, does he use the verb $\mu \mu \varepsilon$ co $\mu \alpha$ ('imitate') or its cognates. Instead, each tribe considers the relevant mythological example via a wide variety of verbs, some of which denote a process of mental deliberation and choice, others denoting pre-formed or assumed knowledge, understanding, or belief. ${ }^{48}$ In some cases, it is hinted that the fictional

\footnotetext{
${ }^{46}$ Grethlein, Greeks and their past (n.7, above) 116.

${ }^{47}$ Loraux, Invention (n.1, above) 111.

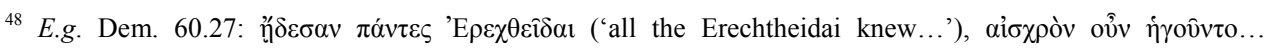

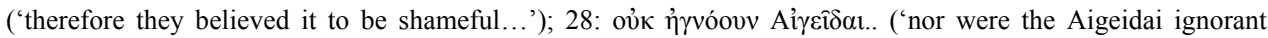

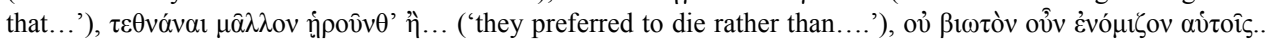
('they considered that life was not worth living...'); 29: oủ $\theta \varepsilon \mu 1 \tau$ òv $\alpha$ io
} 
and fabulous status of the myth was all too clear to the men (60.29-30). Sometimes the logic of exemplarity is strained. But in all cases, Demosthenes is careful to spell out that each tribal unit underwent an act of reasoning, which took them from the myth to a belief that death in battle should not be shirked. Thus, we have a complicated picture in which the stories of named mythical figures have facilitated ten different sub-groups within the city's army to die for their country via ten different thought processes. To assimilate this mixture of 'groupthink' and individuation to unthinking collective imitation of past examples is to miss the way in which Demosthenes' catalogue acknowledges the contribution of membership of different tribal sub-groups and their distinctive identities, knowledge, and memories to the formation of the exemplary Athenian warrior.

\section{(b) Policy and particularity: the voice of the orator.}

The fact that there is an 'I' in the funeral orations is partly a function of the strategic and generic affinities between the epitaphios logos and verse panegyric, especially that of Pindar. ${ }^{49}$ Like Pindar, the orator often reminds his audience that he is making this speech and that he is struggling to say something which is both worthy of the accomplishments of the dead and adequate within an implied contest between the efforts of previous orators and his own. ${ }^{50}$ But we will see that this sort of self-referentiality is not fully explained by a generic expectation that the orator will riff creatively (albeit not too creatively) upon certain topoi to do with the difficulty of the task of praise and the orator's awareness of precedent.

Furthermore, an orator does not have to use the first-person pronoun in order to talk about himself: the markers of self-reference in a speech can be oblique, allusive, and highly dependent on the interaction between the speech, its audience, and the particular context of performance. In this section I will argue that four of the extant funeral speeches exhibit explicit and oblique moments of self-reference, which are geared towards the justification and/or promotion of political-cum-military policies that are associated with both the individual orator himself and the latest season's military campaign. Indeed, it is likely that on some occasions, orators were chosen and their speeches were shaped in order to highlight a politician's responsibility for a particular campaign.

I am aware that this is an anachronistically modernizing thesis if taken too far. The endemic nature of warfare and the militarized culture of Athens in the Classical period meant that Athenians were much more tolerant of the last year's losses than we moderns. ${ }^{51}$ However, there is plenty of evidence to suggest that yearly losses and draining campaigns led to the airing of disquiet and questioning in the democracy's public gatherings. ${ }^{52}$ It is also

it would be heinous for them...'). Shear, 'Politics of remembrance' (n.7, above) acutely observes that many of these verbal constructions underline and recreate the soldiers' own acts of remembering and thereby activate memory and knowledge in the speech's auditors.

${ }^{49}$ Carey, 'Epideictic oratory' (n.12, above) 245. The funeral orator sometimes explicitly compares his task with that of poets: Lys. 2.2; Dem. 60.9 .

${ }^{50}$ E.g. Lys. 2.1-2; Dem. 60.1-3, 9; Hyp. 6.1-9.

${ }^{51}$ See D. M. Pritchard, 'The symbiosis between democracy and war: The case of ancient Athens' in War, Democracy and Culture in Classical Athens, ed. D. M. Pritchard (Cambridge 2010) 1-62 and Low, 'Commemoration' (n.6, above) 342-43.

${ }^{52}$ E.g. Thuc. 2.59-65; Ar. Lys. 551-97; Aeschin. 3.134-36 and 3.152-58. 
clear that individual Athenian politicians and generals were keen to associate themselves with certain campaigns and that such associations took hold in public discourse.

Let us start with evidence which is external to the speeches themselves. The fact that the orator who was to deliver this annual oration was elected to do so via a democratic process is significant. Thucydides describes the custom thus: "when they [sc. the dead] lie hidden in the earth, a man chosen by the city who is of recognized intellectual ability and outstanding reputation, speaks an appropriate eulogy over them' (Thuc. 2.34). ${ }^{53}$ This stress on the speaker's high intellectual reputation as a criterion for selection is undoubtedly connected to the fact that we are about to hear Pericles' oration. In Plato's Menexenus, it is made clear that the specific responsibility for organizing the ceremony and selecting the orator lies with the Boule (Menex. 234b). Menexenus reveals that the Council has delayed its choice of orator to the following day. This could be a dig at the inefficiency of the oratory-obsessed democracy. Even so, it indicates that the decision was not taken lightly and probably involved debate. It is very hard to know what to make of Menexenus' guess that the Boule will pick 'Archinus or Dion'. Archinus was a key politician within the democratic faction at Phyle and fourthcentury BC sources represent him as instrumental in the amnesty and restoration of democracy in 403/402. It is unclear who Dion is. ${ }^{54}$ But we should at least canvass the possibility that Archinus' status as a hero of the democratic cause and the author of specific policies and prosecutions in the aftermath of the civil war is being seen as salient. Archinus is a likely choice, not just because he is a wise man and good orator, but because there is a perceived connection between his political actions and the dead who are to be praised.

The best evidence that responsibility for specific policy positions and close association with campaigns were sometimes factored into the selection process comes in Demosthenes' defence of his political career in On the Crown (18.285):

Our city owes to me, Aeschines, both the inception and the success of many great and noble enterprises. Nor did she forget this. It is a proof of her gratitude that, when the people asked for one who should speak over the bodies of the slain, shortly after the battle, you were nominated but they did not vote for you, in spite of your beautiful voice, nor Demades, although he had recently arranged the peace, nor Hegemon, nor any of your cronies: they voted for me. Then you came forward, and Pythocles with you - and, by Zeus and the gods! how savagely and shamelessly you spoke! - making the very same charges that you have repeated today. But, for all your abusive slanders, they voted for me all the more decisively. ${ }^{55}$

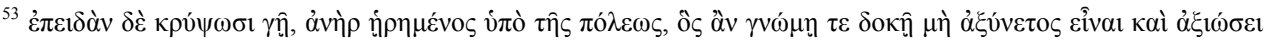

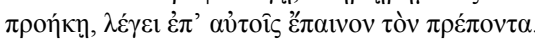

${ }^{54}$ See, however, Monoson, Democratic entanglements (n.14, above) 184-85. Monoson develops Loraux's suggestion that Dion is Plato's Syracusan friend and paradigmatically good politician of the same name (see Pl. Letter 7 and Letter 8). She argues that Menexenus' mention of two impossible choices (Archinus was 'too brutal' and Dion was a non-Athenian) is a thematically salient joke which underlines the irony of Socrates' speech. In 392 an Athenian ambassador called Dion went to Tiribazes (Xen. Hell. 4.8.13).

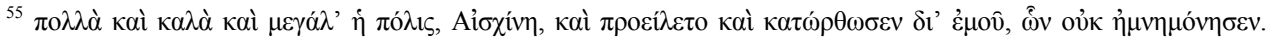

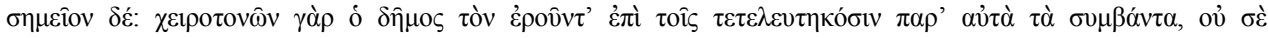

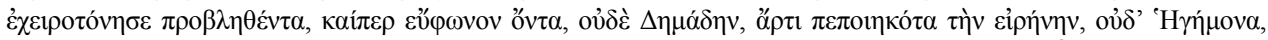

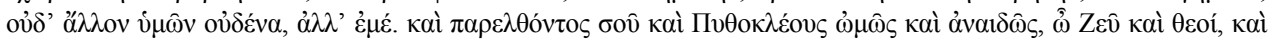

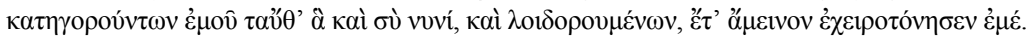


Here, Demosthenes may be exaggerating his popularity and misrepresenting the precise reasons why, eighteen years earlier, he had been elected to deliver the oration over the unusually large number of Athenian dead from Chaeronea. But for this passage to make any sense to the jury, it must present a plausible picture of what was held to be at stake in the selection of the orator. It bears witness to the intense contests between prominent individuals which could constitute the selection process - contests which invoked specific policies and reputations. As Demosthenes sees it, the vote for him as opposed to other politicians was an endorsement of his policies and career up to and including his responsibility for Chaeronea. Perhaps the vote was really or partly a means of getting Demosthenes to face the disastrous consequence of his policies in public. Either way, Demosthenes' account of the political fuss surrounding his selection suggests that the import and meaning of a funeral speech must sometimes have been freighted with the auditors' awareness of the specific identity and policies of the orator delivering it.

When we come to the content of the orations themselves, it is surprising how good a case can be made for the fifth-century examples being highly reflective of the orator's specific political and military policies and responsibilities. It is clear that when Pericles delivered a funeral oration over those who had died securing victory in the Samian campaign, he was doing so as the general who had been its chief political advocate as well as commanding the troops in the gruelling nine-month fight. In recalling Pericles' speech of 439, Plutarch reproduces the critical appraisal of Stesimbrotus (Plut. Per. $8.6=$ Stesimbrotus, FGrH 107 F9):

Again, Stesimbrotus says that, in his praise over those who had died in Samos from the platform, he said that they had become immortal, like the gods: "we cannot see the gods themselves, but from the honours which they receive, and the blessings which they bestow, we conclude that they are immortal." So it was, he said, with those who had given their lives for their fatherland. ${ }^{56}$

Bosworth uses this to point to a contrast between the 439 speech and Pericles' oration of $431 .{ }^{57}$ Where the former revelled in the glory of the occasion and the achievements of the Samian campaign, the latter was sombre and deliberately designed to gloss over the lacklustre military achievements of that year. It orientated and placated all the refugees that had crowded inside the city walls while their vines and farms were raided by the Peloponnesian forces. The Thucydidean speech of 431 is similar to Hyperides' speech, but even more than the latter, the former eschews reference to the successes of the past and directs its eulogy 'to the audience and above all to the speaker'. ${ }^{5}$

Bosworth also draws analogies between the 439 oration and Hyperides' funeral speech. For example, both speeches clearly dwelled on the successes of the immediate campaign and the immortality of the fallen. Plutarch's paraphrase of Ion's testimony at the

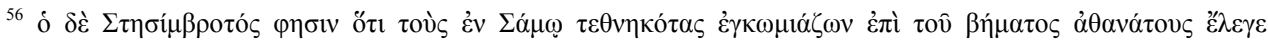

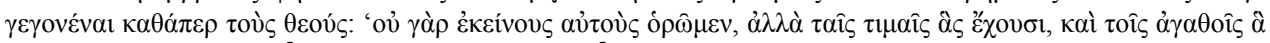

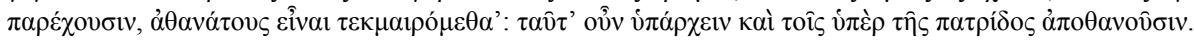

${ }^{57}$ Bosworth, 'Historical context' (n.9, above) 3-4.

${ }^{58}$ Bosworth, 'Historical context' (n.9, above) 4.
} 
end of the following passage may even imply that Pericles' 439 speech boasted that his campaign had surpassed the achievements of Homer's heroes (Plut. Per. 28.3-6):

... for the oration which he made, according to the custom, over their tombs, he won the greatest admiration. But as he came down from the platform, while the rest of the women clasped his hand and fastened wreaths and bands on his head, as if he were some victorious athlete, Elpinice came close and said: 'This is admirable of you, Pericles, and deserving of wreaths, in that you have lost us many brave citizens, not in a war with Phoenicians or Medes, like my brother Cimon, but in the subversion of an allied and kindred city'. On Elpinice's saying this, Pericles, with a quiet smile, it is said, quoted to her the verse of Archilochus (F 205 West): 'Although you are an old woman, you have not perfumed yourself'. Ion ( = FGrH $392 \mathrm{~F} 16)$ says that he had the most astonishingly great thoughts of himself for having subjected the Samians; whereas Agamemnon was all of ten years in taking a barbarian city, he had in nine months overpowered the foremost and most powerful people of Ionia. ${ }^{59}$

Perhaps Ion is referring to what Pericles actually said in his oration - or something similar but more appropriately oblique by way of self-promotion. If that is so, we then have a fifthcentury precedent for a similar conceit in Hyperides (6.35-36). ${ }^{60}$ The story about Pericles being mobbed by female groupies, Elpinice's barbed dissent, and Pericles' insulting reply may be apocryphal. But scholars have adduced other evidence that upper-class women present at the funeral ceremony may have given voice to their support or their unhappiness in 'the highly charged atmosphere of such occasions'. ${ }^{61}$ I think it is reasonable to assume that Pericles' 439 speech would have been implicitly self-aggrandizing even if it only overtly eulogized those who had given their lives in the Samian victory. The Plutarch anecdote certainly suggests that the female audience related the speech to the policy of its speaker and saw its performance as an occasion to praise or criticize his responsibility for that policy.

Hyperides does not explicitly praise himself, of course, but Leosthenes and his fallen warriors are similarly exalted so as to make the recent victories the most glorious ever. Hyperides' long-held anti-Macedonian militarism and his more recent support for the Greek revolt must have meant that this glory reflected back on him. He may have 'taken advantage of his current situation to magnify the results of his own policy'. ${ }^{62}$ As Ian Worthington points out, the speech insinuates that the city's decision to revolt in 323

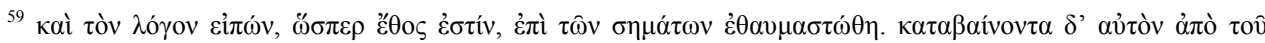

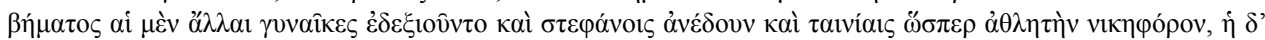

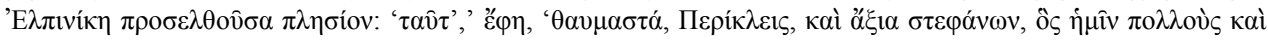

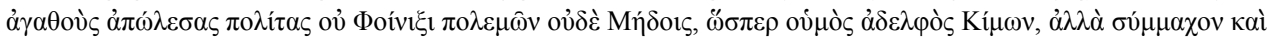

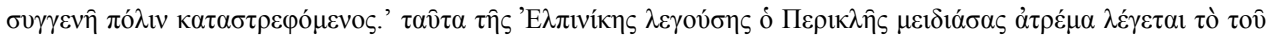

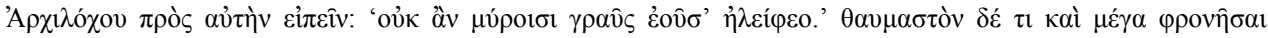

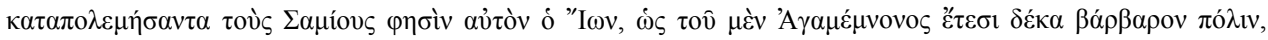

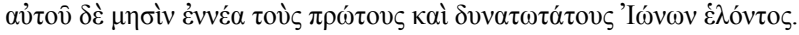

${ }^{60}$ For earlier fourth-century parallels outside the genre of the epitaphios logos see Isoc. 4.83, 5.111, 9.65.

${ }^{61}$ Hardwick, 'Philomel and Pericles' (n.7, above) 153-60 (quotation at 145); Bosworth, 'Historical context' (n.9, above) 1-4.

${ }^{62}$ I. Worthington, Greek orators II. Dinarchus and Hyperides (Warminster 1998) 207.
} 
(aided and abetted by Leosthenes) was better than any previous policy (Hyp. 6.3). ${ }^{63}$ Hyperides' politics and likely closeness to Leosthenes probably explain why he was chosen to deliver the speech in the first place. ${ }^{64}$ Worthington also speculates that Hyperides' speech was designed to negotiate a mood of pessimism in Athens: no one really thought that Athens could win this war in the long run, despite the successes of the first year. Hyperides' glowing account of Leosthenes' campaign in comparison with previous great battles of history constitutes an argument that, by going down fighting, the Athenians will outshine all previous examples of courage and patriotism.

But it is equally possible that Hyperides' speech was delivered in an atmosphere of cautious hope given that Athens had been successful so far. Either way, Hyperides may also have felt that, pour encourager les autres, citizens needed to hear that that a general who had paid with his life for his commitment to the city's liberation would get extraordinary recognition. This, after all, is compatible with the sort of exemplary functioning which decrees awarding crowns to public benefactors fulfilled in the postChaeronea period. ${ }^{65}$ If we consider the fates of Hyperides' and Demosthenes when the resistance effort was crushed, the funeral speech of 322 sent the message that elite leaders who put their necks on the line (and who would almost certainly be killed or exiled if the war was not won) could expect to be named and praised.

Much more than the other speeches, Demosthenes' funeral oration returns again and again to the difficulty of speaking appropriately, of getting the length right and of being adequate to the challenge. ${ }^{66}$ Demosthenes also goes furthest in signposting the structure of the speech and in explaining the choices he is making as he goes along. ${ }^{67}$ Nearly all of this is done via first person singular verbs and the occasional 'royal we'. It is as if Demosthenes, the architect of the disaster at Chaeronea, is undergoing a 'masochism strategy' by facing the relatives of the men who died and were defeated. To take one example, Demosthenes at one point says he must pause and 'appeal to the goodwill' of the metics and foreigners listening to him (60.13). He argues that if he had been commissioned to support the ceremony financially or by organizing its equestrian or gymnastic spectacles, he would easily have been felt to have done his duty appropriately. But giving the speech is a different matter: he fears that without the sympathy of his hearers, and despite his enthusiasm, he will achieve the opposite of what he should. Even the most persuasive orator will be thwarted if he does not have the goodwill of his audience (60.14). Now this captatio benevolentiae sounds superficially similar to that of Pericles (Thuc. 2.35). But Pericles is much more contemptuous of the custom he has been required to uphold and much more sanguine about the impossibility of satisfying his audience's varied expectations and wishes. Where Demosthenes fearfully begs indulgence, Pericles just says he will make the best of a bad job.

\footnotetext{
${ }^{63}$ Worthington, Greek orators II (n.62, above) 206-07.

${ }^{64}$ Plut. Mor. 486d pairs up Leosthenes and Hyperides, but see Herrman Funeral speech (n.16 above) 61 for problems and bibliography. They might have been friends given that both were instrumental in moving against Macedon with an optimism and opportunism that heralded the end of the post-Chaeronea hangover.

${ }^{65}$ See H. Yunis, Demosthenes on the crown (Cambridge 2001) 7.

${ }^{66}$ Dem. 60.1, 3, 6, 12-14, 15, 23-24, 35, 37.

${ }^{67}$ Dem. 60.1, 3, 6, 9, 12, 13, 15, 27, 35.
} 
But Demosthenes also represents Chaeronea as a necessary confrontation between freedom and despotism. The dead are praised for wisely anticipating the threat of Macedon in terms which explicitly mirror Demosthenes' own self-representation of his long-held foresight and warnings about the threat of Philip in On the Crown. ${ }^{68}$ Indeed, he comes close to blaming their deaths on those who chose to do nothing about Macedon when it 'was still possible to avert these misfortunes without sacrificing safety' (60.18).

So, while there are no named generals or political opponents in Demosthenes' speech, the explicit and frequent use of first person verbs and the oblique gestures of political self-justification mean that 'Demosthenes the rhetor' is very much in Demosthenes' speech. To characterize it as a simple affirmation of collective hoplite sacrifice in the name of Greek freedom is to miss the particularity and policy justifications which the orator's voice carries with it.

\section{(c) Conclusion}

None of the above unravels the most important insights of Loraux's brilliant book. But I have shown that some epitaphioi logoi were more about the naming, praising, memorializing, and justifying of individuals and sub-groups than is often assumed. It seems most likely that the first two decades of the fourth-century BC entailed a granting of a limited licence to name individual leaders from campaigns from the fifth century and a concomitant interest in acknowledging sub-groups of citizens. But the paucity of fifth-century evidence makes this a conjecture based on documented shifts towards more commemoration of individuals' deaths with private monuments and the granting of visible honours to current generals and benefactors.

When the people voted for an orator who had some claim to responsibility for a stunning military success for the city, he could push the boundaries of propriety to project implicit selfglorification and that of his elite associates. Of course, the rank and file still had to be celebrated and situated alongside those who had died in earlier conflicts. But the way in which this was done and the extent to which it needed to be done was subject to more variation than 'a more or less fixed form that repeated the same topoi over and over' ${ }^{69}$ Victory gave licence to a leader to assert the importance of leadership and his role in a campaign. And even a defeat allowed - perhaps sometimes required - an elite individual who had led and/or advocated the relevant campaign to justify the deaths and speak (albeit obliquely) to his inevitable association with the dead. He could make sense of the reason why they were dead in relation to his own vision and strategy. But this was achieved through (and despite) the conventions of the genre: those conventions were less 'immobile' than is often assumed. ${ }^{70}$

School of Classics, University of St Andrews

\footnotetext{
${ }^{68}$ Dem. 60.18; Dem. 18.19-20, 62

${ }^{69}$ Grethlein, Greeks and their past (n.7, above) 122.

${ }^{70}$ Thanks to audiences at the ICS and Glasgow's workshop on the funeral speeches, and to Mike Edwards and Julia Shew for comments and criticism.
} 